\title{
Evolution Pattern of Technical Innovation Input and Output of Agricultural Product Processing Industry in China
}

\author{
Li Yifeng, Zheng Chuanfang* \\ School of Management, Fujian Agriculture and Forestry University \\ Fuzhou 350002
}

\begin{abstract}
Based on the data of China Statistical Yearbook, this paper conducts the quantitative analysis about the technical innovation input and output conditions of Chinese agricultural product processing industry, and it finds that: firstly, in the agricultural product processing industry, the input strength of $R \& D$ personnel, $R \& D$ fund and new product development is in the period of low level; secondly, there is bigger promotion space for the technical innovation achievement output capacity and new product development capacity for the agricultural product processing industry, and the ratio of unit production value output patent quantities and new product sale incomes in the sale incomes is still relatively low; thirdly the ratio of invention patent for the agricultural product processing industry in the patent application quantity is relatively low, which indicates that the output capacity for substantive technical innovation achievement is low and bad for the transformation upgrading of agricultural product processing industry and the promotion of international competitiveness.
\end{abstract}

Keywords-Agricultural product processing industry; R\&D input; Patent; New products

\section{INTRODUCTION}

The promotion of development capacities for agricultural product processing enterprise is the important assurance and boosting factors to solve "three-agricultural problems", realize the agricultural supply-side structural reform, and implementing rural revitalization strategies. The promotion of technical innovation capacity for agricultural product processing enterprise is the key for developing the capacity. Under such background, this paper conducts quantitative analysis on the R\&D input and $R \& D$ output of Chinese agricultural product processing industry, help the decisionmakers master the R\&D conditions about the enterprises of agricultural product processing industry, and provide reliable fact basis for political design.

\section{VARIABLE DESIGN AND DATA SOURCE}

The complete measurement of technical innovation capacity for agricultural product processing enterprise should be conducted from two aspects, i.e., the technical innovation input and innovation output. At present, the mostly used technical innovation input measurements index for scholars include R\&D expenditure output and R\&D personnel input (Chu Deyin et al., 2016), the new product development expenditure output, the ratio of $R \& D$ input in sales incomes (Costantini et al., 2015); but the innovation output measurement index mainly includes patent application quantity (Li Wenjing and Zheng Manni, 2016), new product production value or sales incomes (Zhao Zhonghua and $\mathrm{Ju}$ Xiaofeng, 2013). Li Wenjing and Zheng Manni (2016) along with Li Yongyou and Ye Qianwen (2017) further divided patent application quantity into invention patent application quantity and non-invention patent (new utility model patent and appearance design patent), and respectively investigated the substantive innovation and strategic innovation of enterprises. To sum up, this paper selects the quantity of $R \& D$ personnel averagely owned by each enterprise, the ratio of R\&D expenditures in sales incomes, and the ratio of new product development expenditures in sales incomes to reflect the technical innovation input of agricultural product processing industry; uses unit output value output patent quantities, the ratio of invention patent in patent application quantities, and the ratio of new product sales incomes in sales incomes to reflect the technical innovation output of agricultural product processing industry. Relative number rather than absolute number is adopted for measurement, and the main reason is that: as per the Industrial Classification Guidance of Listed Companies published by CSRC in 2012, the agricultural product processing industry includes 12 subdivided industries, i.e., the farm and sideline food processing industry, food manufacturing industry, beverage manufacturing industry, tobacco manufacturing industry, textile industry, paper making and paper product industry, and there are obvious differences in the development level, scale, technical density degree and other aspects of different subdivided industries, and the adoption of relative number possesses more comparability and accuracy.
Author: Li Yifeng (1978- ), male, Doctoral Candidate, School of

Management in Fujian Agriculture and Forestry University,

53165037@qq.com.

Corresponding Author: Zheng Chuanfang (1953- ), Professor, School of Management in Fujian Agriculture and Forestry University. 
The original data requested for the calculation of the aforementioned 6 indexes are from China Statistical Yearbook, and are specifically the observation data about the enterprises above designated size within all subdivided industries of agricultural product processing industry. Since that, among the aforementioned indexes, the statistical caliber from 2012 to 2016 clarified rubber product manufacturers and plastic products into the same industry, i.e., the rubber and plastic products industry, and the industry doesn't fully belong to the range of agricultural product processing industry, so this paper doesn't include the industry into the range of analysis. Besides, tobacco product enterprises are state-owned enterprises, with relatively strong particularity, it is not included into the range of analysis in this paper.

\section{EVOLUTION CHARACTERISTICS ABOUT THE RESEARCH INPUT OF CHINESE AGRICULTURAL PRODUCT PROCESSING INDUSTRY}

\section{A. Evolution Characteristics about the Manpower Input and Fund Input Strength of Technical Innovation}

Use the R\&D personnel quantity averagely owned by enterprises above designated size within the subdivided industry to measure the technical innovation manpower input strength, and it is specifically as follows: firstly, as a whole, the technical innovation manpower input strength for agricultural product processing enterprises is low. $R \& D$ personnel quantity averagely owned by enterprises above designated size within the subdivided industry of agricultural product processing industry is still quite few, and the quantity of $R \& D$ personnel averagely owned by each enterprise is no more than 4 people. Secondly, as can be seen from the vertical comparison of single subdivided industry, from 2011 to 2016, except wine, drink and refined tea manufacturing industry, the technical innovation manpower input strength for the rest industries presented a trend of increase, and the top 3 industries with the fastest increase respectively included wood processing and bamboo vine brown grass product manufacturing industry, furniture manufacturing industry, and papermaking and paper product industry, and the average increase rate was respectively $32.34 \%, 24.19 \%$ and $14.10 \%$. thirdly, as can be seen from horizontal comparison, the technical innovation manpower input strength was relatively high in 4 industries with intensive fund, including papermaking and paper product industry, food manufacturing industry, wine, beverage and refined tea manufacturing industry and textile industry, but the technical innovation manpower input strength was relatively low in Farm and sideline food processing industry and wood processing and bamboo vine brown grass product manufacturing industry with intensive labor force or intensive raw materials.

TABLE I.

QUANTITY OF R\&D PERSONNEL AVERAGELY OWNED BY EACH ENTERPRISE

UNIT: PERSON/QUANTITY

\begin{tabular}{|c|c|c|c|c|c|c|c|}
\hline Index & 2011 & 2012 & 2013 & 2014 & 2015 & 2016 & $\begin{array}{c}\text { Average } \\
\text { Increase } \\
\text { Speed }\end{array}$ \\
\hline Farm and sideline food processing industry & 1.204 & 1.361 & 1.593 & 1.731 & 1.710 & 1.897 & 11.51 \\
\hline Food manufacturing industry & 2.848 & 3.213 & 3.480 & 3.505 & 3.611 & 3.747 & 6.32 \\
\hline $\begin{array}{l}\text { Wine, drink and refined tea manufacturing } \\
\text { industry }\end{array}$ & 4.106 & 4.279 & 3.582 & 3.720 & 3.151 & 3.156 & -4.63 \\
\hline Textile industry & 2.217 & 2.366 & 2.518 & 2.731 & 3.006 & 3.222 & 9.07 \\
\hline $\begin{array}{l}\text { Textile cloth, shoes, and hat manufacturing } \\
\text { industry }\end{array}$ & 1.468 & 2.071 & 2.185 & 1.823 & 2.064 & 2.219 & 10.24 \\
\hline $\begin{array}{l}\text { Leather, fur, and feather (leather) and the } \\
\text { manufacturing industry }\end{array}$ & 1.309 & 1.483 & 1.598 & 1.822 & 2.031 & 2.223 & 13.97 \\
\hline $\begin{array}{l}\text { Wood processing and wood, bamboo, palm fiber, } \\
\text { and straw product manufacturing industry }\end{array}$ & 0.566 & 0.796 & 0.924 & 1.122 & 1.326 & 1.480 & 32.34 \\
\hline Furniture manufacturing industry & 1.166 & 1.667 & 1.848 & 2.142 & 2.115 & 2.575 & 24.19 \\
\hline Papermaking and paper product industry & 2.157 & 2.521 & 2.910 & 3.313 & 3.454 & 3.678 & 14.10 \\
\hline $\begin{array}{l}\text { Printing industry and record media copying } \\
\text { industry }\end{array}$ & 2.153 & 2.235 & 2.241 & 2.318 & 2.429 & 2.872 & 6.69 \\
\hline
\end{tabular}

Use the ratio of $\mathrm{R} \& \mathrm{D}$ expenditures in sales incomes to measure the technical innovation fund input strength. As a whole, the technical innovation fund input strength of agricultural product processing industry is very low, and the ratio of $R \& D$ expenditures for enterprises above designated size within 10 subdivided industries of agricultural product processing industry in sales income is less than $1 \%$, with extremely few difference, of which the technical innovation fund input strength in papermaking and paper product industry, food manufacturing industry, printing industry and record media copying industry with intensive fund is the highest.
However, as can be seen from vertical comparison, the innovation fund input strength for most subdivided industries of agricultural product processing industry presents a relatively fast increase speed. Except wine, drink and refined tea manufacturing industry, from 2011 to 2016, the technical innovation fund input strength for the rest industries presented increase characteristics, and the Increase Speed in furniture manufacturing industry, leather, fur, and feather (leather) and the manufacturing industry, wood processing and bamboo vine brown grass product manufacturing industry was the fastest, and the average increase rate was respectively $33.51 \%$, 
$23.92 \%$ and $22.40 \%$. Besides, textile cloth, shoes, and hat manufacturing industry, papermaking and paper product industry, farm and sideline food processing industry also presented a relatively fast increase speed.

TABLE II. RATIO OF R\&D EXPENDITURES IN SALE INCOMES UNIT: \%

\begin{tabular}{|c|c|c|c|c|c|c|c|}
\hline Index & 2011 & 2012 & 2013 & 2014 & 2015 & 2016 & $\begin{array}{c}\text { Average } \\
\text { Increase } \\
\text { Speed }\end{array}$ \\
\hline Farm and sideline food processing industry & 0.213 & 0.263 & 0.29 & 0.308 & 0.328 & 0.363 & 14.09 \\
\hline Food manufacturing industry & 0.454 & 0.558 & 0.546 & 0.566 & 0.619 & 0.649 & 8.6 \\
\hline $\begin{array}{c}\text { Wine, drink and refined tea manufacturing } \\
\text { industry }\end{array}$ & 0.601 & 0.605 & 0.546 & 0.603 & 0.511 & 0.529 & -2.4 \\
\hline Textile industry & 0.424 & 0.434 & 0.447 & 0.471 & 0.527 & 0.546 & 5.74 \\
\hline $\begin{array}{l}\text { Textile cloth, shoes, and hat manufacturing } \\
\text { industry }\end{array}$ & 0.219 & 0.323 & 0.357 & 0.352 & 0.404 & 0.452 & 21.2 \\
\hline $\begin{array}{l}\text { Leather, fur, and feather (leather) and the } \\
\text { manufacturing industry }\end{array}$ & 0.177 & 0.246 & 0.271 & 0.289 & 0.347 & 0.389 & 23.92 \\
\hline $\begin{array}{l}\text { Wood processing and wood, bamboo, palm fiber, and } \\
\text { straw product manufacturing industry }\end{array}$ & 0.165 & 0.182 & 0.225 & 0.243 & 0.303 & 0.35 & 22.40 \\
\hline Furniture manufacturing industry & 0.182 & 0.257 & 0.339 & 0.368 & 0.414 & 0.486 & 33.51 \\
\hline Papermaking and paper product industry & 0.473 & 0.604 & 0.677 & 0.7 & 0.757 & 0.828 & 14.99 \\
\hline $\begin{array}{l}\text { Printing industry and record media copying } \\
\text { industry }\end{array}$ & 0.501 & 0.542 & 0.501 & 0.497 & 0.492 & 0.572 & 2.81 \\
\hline
\end{tabular}

B. Evolution Characteristics about the Development Input Strength of New Products

Use the ratio of new product development expenditures in sales incomes to measure the new product development input strength. As a whole, the new product development input strength for agricultural product processing enterprise is also very low, and the ratio of new product development expenditures for enterprises above designated size within 10 subdivided industries of agricultural product processing industry in sales income is less than $1 \%$, with extremely few difference, of which the new product development input strength in papermaking and paper product industry, food manufacturing industry, and furniture manufacturing industry with intensive fund is the highest. However, as can be seen from the vertical comparison of single subdivided industry, from 2011 to 2016, except wine, drink and refined tea manufacturing industry, printing industry and record media copying industry, the new product development input for the rest industry presents increase trend, and the Increase Speed for Furniture manufacturing industry, Leather, fur, and feather (leather) and the manufacturing industry, wood processing and bamboo vine brown grass product manufacturing industry was the fastest, and the average increase rate was respectively $29.03 \%, 19.16 \%$ and $16.90 \%$.

TABLE III. RATIO OF NEW PRODUCT DEVELOPMENT EXPENDITURES IN SALE INCOMES

UNIT: \%

\begin{tabular}{|c|c|c|c|c|c|c|c|}
\hline Index & 2011 & 2012 & 2013 & 2014 & 2015 & 2016 & $\begin{array}{c}\text { Average } \\
\text { Increase } \\
\text { Speed }\end{array}$ \\
\hline Farm and sideline food processing industry & 0.277 & 0.312 & 0.359 & 0.354 & 0.344 & 0.398 & 8.81 \\
\hline Food manufacturing industry & 0.495 & 0.576 & 0.582 & 0.661 & 0.632 & 0.674 & 7.23 \\
\hline Wine, drink and refined tea manufacturing industry & 0.621 & 0.624 & 0.622 & 0.514 & 0.426 & 0.470 & -4.85 \\
\hline Textile industry & 0.515 & 0.554 & 0.538 & 0.543 & 0.528 & 0.554 & 1.49 \\
\hline Textile cloth, shoes, and hat manufacturing industry & 0.305 & 0.434 & 0.444 & 0.413 & 0.415 & 0.504 & 13.11 \\
\hline $\begin{array}{l}\text { Leather, fur, and feather (leather) and the } \\
\text { manufacturing industry }\end{array}$ & 0.240 & 0.297 & 0.033 & 0.353 & 0.385 & 0.470 & 19.16 \\
\hline $\begin{array}{l}\text { Wood processing and wood, bamboo, palm fiber, and straw } \\
\text { product manufacturing industry }\end{array}$ & 0.183 & 0.234 & 0.249 & 0.275 & 0.304 & 0.338 & 16.90 \\
\hline Furniture manufacturing industry & 0.260 & 0.369 & 0.428 & 0.467 & 0.517 & 0.638 & 29.03 \\
\hline Papermaking and paper product industry & 0.538 & 0.591 & 0.613 & 0.601 & 0.612 & 0.790 & 9.40 \\
\hline Printing industry and record media copying industry & 0.579 & 0.635 & 0.541 & 0.495 & 0.497 & 0.577 & -0.05 \\
\hline
\end{tabular}




\section{EVOLUTION CHARACTERISTICS ABOUT THE R\&D OUtPut OF CHINESE AgRICUlTuRAL PRODUCT PROCESSING INDUSTRY}

\section{A. Variation Trend of Patent Output}

Use unit output value output patent quantities to measure the patent output capacity (the ratio of patent application quantity in sales incomes). According to the aforementioned contents, we can know that, most technical innovations in the subdivided industries of agricultural product processing industry has wider range of improvement, but the technical innovation manpower input and fund input strength are still under an extremely low level. Thus, the patent output capacity for various subdivided industries of agricultural product processing industry is also under an extremely low level. The patent application quantity supported by RMB 100 million of sales incomes is bigger than 1 for merely the furniture manufacturing industry (which was 1.204 in 2016), and that for all the rest subdivided industries is far less than 1 , which indicates that there is still a big room for the improvement of technical innovation capacity for agricultural product processing industry. But as can be seen from vertical comparison, from 2011 to 2016, merely furniture manufacturing industry, papermaking and paper product industry, leather, fur, and feather (leather) and the manufacturing industry, farm and sideline food processing industry presented relatively obvious increase trend, and the average increase trend was respectively $16.34 \%, 15.57 \%$, $10.13 \%$, and the patent output Increase Speed for the rest subdivided industries was slow, and negative increase situation even occurred in textile industry.

table IV. Unit Output Value OutPut Patent Quantity Unit: Piece/Hundred Million Yuan

\begin{tabular}{|c|c|c|c|c|c|c|c|}
\hline Index & 2011 & 2012 & 2013 & 2014 & 2015 & 2016 & $\begin{array}{c}\text { Average } \\
\text { Increase } \\
\text { Speed }\end{array}$ \\
\hline Farm and sideline food processing industry & 0.101 & 0.115 & 0.123 & 0.133 & 0.138 & 0.146 & 9.08 \\
\hline Food manufacturing industry & 0.281 & 0.303 & 0.301 & 0.310 & 0.305 & 0.326 & 3.23 \\
\hline $\begin{array}{c}\text { Wine, drink and refined tea manufacturing } \\
\text { industry }\end{array}$ & 0.188 & 0.280 & 0.255 & 0.263 & 0.205 & 0.198 & 0.98 \\
\hline Textile industry & 0.396 & 0.380 & 0.323 & 0.337 & 0.432 & 0.342 & -2.75 \\
\hline $\begin{array}{c}\text { Textile cloth, shoes, and hat manufacturing } \\
\text { industry }\end{array}$ & 0.270 & 0.404 & 0.327 & 0.377 & 0.589 & 0.342 & 5.29 \\
\hline $\begin{array}{l}\text { Leather, fur, and feather (leather) and the } \\
\text { manufacturing industry }\end{array}$ & 0.230 & 0.291 & 0.282 & 0.291 & 0.342 & 0.347 & 10.13 \\
\hline $\begin{array}{l}\text { Wood processing and wood, bamboo, palm fiber, } \\
\text { and straw product manufacturing industry }\end{array}$ & 0.218 & 0.237 & 0.216 & 0.183 & 0.209 & 0.207 & -1.06 \\
\hline Furniture manufacturing industry & 0.663 & 0.690 & 0.729 & 0.682 & 1.151 & 1.204 & 16.34 \\
\hline Papermaking and paper product industry & 0.190 & 0.274 & 0.253 & 0.316 & 0.280 & 0.338 & 15.57 \\
\hline $\begin{array}{l}\text { Printing industry and record media copying } \\
\text { industry }\end{array}$ & 0.338 & 0.435 & 0.473 & 0.452 & 0.441 & 0.453 & 6.81 \\
\hline
\end{tabular}

B. Variation Trend for the New Product Development Achievement

As the terminal achievement for the technical innovation of enterprises, new products are the innovation achievements of enterprises that can be intuitively felt by consumers, and it will directly influence the purchasing desire, purchasing behavior, and use satisfaction degree of consumers, and then directly influence the economic benefit of enterprises. However, since the new product development input strength is very low, it will directly cause the difficulty in obtaining breakthrough in the new product research (design) and development of enterprises above designated size within subdivided industries of agricultural product processing industry. As can be seen from Table 5, the ratio of new product sales incomes in the total sales incomes for enterprises above designated size within subdivided industries of agricultural product processing industry is under a very low level, and has a big room for promotion. In 2016, merely papermaking and paper product industry, textile industry, and furniture manufacturing industry exceeded $10 \%$ on the basis of this rate. Besides, except the 3 subdivided industries of textile cloth, shoes, and hat manufacturing industry, furniture manufacturing industry, papermaking and paper product industry, the increase speed for the ratio of new product sales incomes for the rest subdivided industries in the sales incomes is relatively slow. 
TABLE V. Ratio of New Product Sales in Sale Incomes

\begin{tabular}{|c|c|c|c|c|c|c|c|}
\hline Index & 2011 & 2012 & 2013 & 2014 & 2015 & 2016 & $\begin{array}{c}\text { Average } \\
\text { Increase } \\
\text { Speed }\end{array}$ \\
\hline Farm and sideline food processing industry & 3.39 & 3.88 & 3.56 & 3.88 & 4.33 & 4.84 & 8.53 \\
\hline Food manufacturing industry & 4.94 & 5.42 & 6.08 & 5.82 & 6.10 & 6.81 & 7.58 \\
\hline $\begin{array}{l}\text { Wine, drink and refined tea manufacturing } \\
\text { industry }\end{array}$ & 6.79 & 8.08 & 7.48 & 6.41 & 5.70 & 5.95 & -2.46 \\
\hline Textile industry & 10.15 & 10.61 & 11.43 & 11.43 & 12.04 & 12.84 & 5.32 \\
\hline $\begin{array}{c}\text { Textile cloth, shoes, and hat manufacturing } \\
\text { industry }\end{array}$ & 6.12 & 7.36 & 7.62 & 8.11 & 8.19 & 9.27 & 10.30 \\
\hline $\begin{array}{l}\text { Leather, fur, and feather (leather) and the } \\
\text { manufacturing industry }\end{array}$ & 5.82 & 5.50 & 5.90 & 5.88 & 6.18 & 7.15 & 4.57 \\
\hline $\begin{array}{l}\text { Wood processing and wood, bamboo, palm fiber, } \\
\text { and straw product manufacturing industry }\end{array}$ & 2.81 & 3.14 & 2.78 & 3.51 & 3.78 & 4.03 & 8.70 \\
\hline Furniture manufacturing industry & 5.12 & 5.15 & 5.91 & 6.93 & 7.54 & 10.72 & 21.88 \\
\hline Papermaking and paper product industry & 8.62 & 8.96 & 10.65 & 11.19 & 11.74 & 14.11 & 12.74 \\
\hline $\begin{array}{l}\text { Printing industry and record media copying } \\
\text { industry }\end{array}$ & 7.37 & 8.14 & 7.19 & 7.45 & 7.55 & 7.93 & 1.52 \\
\hline
\end{tabular}

C. Evolution Characteristics about the Substantive Technical Innovation Achievements

Through referring to the research of Li Wenjing and Zheng Manni (2016) as well as Li Yongyou and Ye Qianwen (2017), the patent application quantity is divided into invention patent application and non-invention patent, and meanwhile, the ratio of invention patent in patent application quantity is used to reflect the true technical innovation capacity for enterprises above designated size within agricultural product processing industry. As can be seen from Table 6, utility model patent and appearance design patent are still the subject for the patent application of agricultural product processing enterprises, and the ratio of invention patent in patent application quantity for merely farm and sideline food processing industry and food manufacturing industry is relatively high, which is respectively $45.22 \%$ and $40.08 \%$; the ratio of invention patent in patent application quantity for wine, drink and refined tea manufacturing industry, papermaking and paper product industry, wood processing and wood, bamboo, palm fiber, and straw product manufacturing industry is respectively $35.02 \%$, $33.25 \%$ and $31.75 \%$, and that for the rest subdivided industry is less than $30 \%$, especially for leather, fur, and feather (leather) and the manufacturing industry, furniture manufacturing industry, which are respectively $15.61 \%$ and $15.22 \%$. The aforementioned data indicate that, the substantive technical innovation capacity for agricultural product processing enterprises is still under a relatively low level, which has verified the research of Li Wenjing and Zheng Manni (2016) as well as Li Yongyou and Ye Qianwen (2017) to some extent, and the agricultural product processing enterprises conduct strategic innovation (i.e., utility model patent and appearance design patent application), to obtain various government innovation subsidies or cater for the government subsidy policy, and as can be seen from the long run, it is bad for the transformation upgrading of agricultural product processing industry and the promotion course of international competitiveness, and the Increase Speed is very slow for the ratio of invention patent in patent application quantity considering 6 industries, including farm and sideline food processing industry, food manufacturing industry, wine, drink and refined tea manufacturing industry, wood processing and wood, bamboo, palm fiber, and straw product manufacturing industry, papermaking and paper product industry, printing industry and record media copying industry, and this can provide valid evidences for the aforementioned worries. 


\begin{tabular}{|c|c|c|c|c|c|c|c|}
\hline Index & 2011 & 2012 & 2013 & 2014 & 2015 & 2016 & $\begin{array}{l}\text { Average } \\
\text { Increase } \\
\text { Speed }\end{array}$ \\
\hline Farm and sideline food processing industry & 38.83 & 40.46 & 42.08 & 42.99 & 44.88 & 45.22 & 3.29 \\
\hline Food manufacturing industry & 39.07 & 38.36 & 39.61 & 44.53 & 40.09 & 40.08 & 0.51 \\
\hline $\begin{array}{c}\text { Wine, drink and refined tea manufacturing } \\
\text { industry } \\
\text { Textile industry }\end{array}$ & $\begin{array}{l}27.60 \\
14.59\end{array}$ & $\begin{array}{l}26.87 \\
16.54\end{array}$ & $\begin{array}{l}24.26 \\
1938\end{array}$ & $\begin{array}{l}26.99 \\
2122\end{array}$ & $\begin{array}{l}33.05 \\
21.27\end{array}$ & $\begin{array}{l}35.02 \\
27.61\end{array}$ & $\begin{array}{c}5.38 \\
1786\end{array}$ \\
\hline $\begin{array}{c}\text { Textile industry } \\
\text { Textile cloth, shoes, and hat manufacturing } \\
\text { industry }\end{array}$ & 14.59 & 16.54 & 19.38 & 21.22 & 21.27 & 27.61 & 22.96 \\
\hline $\begin{array}{l}\text { Leather, fur, and feather (leather) and the } \\
\text { manufacturing industry }\end{array}$ & 10.66 & 13.43 & 17.07 & 14.11 & 14.09 & 15.61 & 9.30 \\
\hline $\begin{array}{l}\text { Wood processing and wood, bamboo, palm fiber, and } \\
\text { straw product manufacturing industry }\end{array}$ & 28.27 & 21.54 & 26.39 & 26.75 & 26.75 & 31.75 & 2.47 \\
\hline Furniture manufacturing industry & 9.19 & 9.93 & 12.29 & 15.97 & 13.34 & 15.22 & 13.14 \\
\hline $\begin{array}{c}\text { Papermaking and paper product industry } \\
\text { Printing industry and record media copying } \\
\text { industry }\end{array}$ & 27.60 & 27.95 & 34.23 & 33.97 & 35.23 & 33.25 & 4.09 \\
\hline $\begin{array}{l}\text { V. CONCLUSION } \\
\text { This paper is based on the secondary data } \\
\text { atistical Yearbook, and conducts quantitative ana } \\
\text { chnical innovation input and output conditions } \\
\text { terprises above designated size within } 10 \\
\text { dustries of Chinese agricultural product processin } \\
\text { in the result has found out that: firstly, R\&D pers } \\
\text { rength for agricultural product processing indu } \\
\text { nd input strength and new product developr } \\
\text { rength are under the period of low level; secondly }\end{array}$ & $\begin{array}{l}\text { China } \\
\text { s on the } \\
\text { out the } \\
\text { divided } \\
\text { ndustry, } \\
\text { el input } \\
\text { R\&D } \\
\text { t input }\end{array}$ & \multicolumn{6}{|c|}{$\begin{array}{l}\text { to stimulate (agricultural product processing) enterprise } \\
\text { innovation, the government should conduct refinement as per } \\
\text { the difficulty of innovation behavior, the depth and potential } \\
\text { value, and enlarge the support strength for the earlier stage } \\
\text { considering the R\&D projects with high technical contents, } \\
\text { and promote the substitutive innovation of enterprises. Thirdly, } \\
\text { conduct reasonable guidance and appropriate support for } \\
\text { innovative enterprises with relatively low technical contents, } \\
\text { and during the subsidization of the later period, distinguish the } \\
\text { enterprise innovation achievement, increase the selection } \\
\text { standard, and the overall innovation quality. }\end{array}$} \\
\hline
\end{tabular}

\section{REFERENCES}

product development capacity for agricultural product processing industry have bigger promotion space, and the specific performance is that the ratio of unit output value output patent quantity and new product sales incomes in sales incomes is still relatively low; thirdly, the ratio of invention patent for agricultural product processing industry in patent application quantity is relatively low, which indicates that the substantive technical innovation achievement output capacity is low, and is bad for the transformation upgrading of agricultural product processing industry and the promotion course of international competitiveness.

The political implication of the aforementioned analysis result includes: firstly, the government should enlarge the support strength for the technical innovation of agricultural product processing enterprises, guide agricultural product processing enterprises to enlarge technical innovation talent input and fund input, increase the technical innovation patent achievement and new product design and development achievement; secondly, while formulating industrial policies

[1] Costantini V, Crespi F, Palma A. Characterizing the Policy Mix and Its Impact on Eco-innovation: A Patent Analysis of Energy-efficient Technologies [J]. Research Policy, 2017, 46.

[2] Chu Deyin, Yang Shan and Song Genmiao. Innovation Input of Fiscal Subsidies, Tax Preference and Strategic Emerging Industry [J]. Finance and Trade Research, 2016(5):83-89.

[3] Li Wenjing and Zheng Manni. Substantive Innovation or strategic innovation?-Influence of Macroscopic Industry Policy on the Innovation of Microscopic Enterprises [J]. Economic Research, 2016(4):60-73.

[4] Li Yongyou and Ye Qianwen. Incentive Effect of Government Scientific and technical Innovation Subsidies and the Recognition of Mechanism - Research about the Experience Based on the Microcosmic Data of Enterprises [J]. Collected Essays on Finance and Economics, 2017, 228(12):22-32.

[5] Zhao Zhonghua and Ju Xiaofeng. Research about the Influence of Technology Spillover and Government Subsidies on the Technical Innovation Activity of Military Industrial Enterprises-Empirical Analysis Based on the Listed Military Industrial Enterprises in Our Country [J]. China Soft Science, 2013(10):124-133. 